\title{
Limitations of Panoramic Radiographs: Report of Two Cases
}

\section{Panoramik Radyografilerin Kısıtlılıkları: Iki Olgu Sunumu}

\section{Nihat DEMIRTAŞ ${ }^{1}$, Ahmet MIHMANLI ${ }^{1}$, Emre AYTUGAR ${ }^{2}$, Suzan BAYER ${ }^{1}$ \\ ${ }^{1}$ Department of Oral and Maxillofacial Surgery, Bezmialem Vakif University, Istanbul, Turkey \\ 2Department of Oral and Maxillofacial Radiology, Bezmialem Vakif University, Faculty of Dentistry, Istanbul, Turkey}

\section{ABSTRACT}

Panoramic radiographs are valuable and technically easy procedures in determining lesions and the other pathological conditions of the jaw. However, it should be recognized that there are obvious limitations in these films. These limitations include distortions, magnifications, and difficulties in identifying the relationship of the lesions with vital structures.

This study presented two cases that indicated the limitations of panoramic radiographs. In the first case, a radiolucent lesion was detected on panoramic radiography. The borders of the lesion were associated with the mandibular canal and mental foremen. In the second case, two radiolucent areas were seen on panoramic radiography. They were determined to be in relation to the maxillary sinus and mental foramen. Following the screening panoramic examination, cone beam computed tomography (CBCT) was obtained in both of the cases. The CBCT views demonstrated no relationship between the lesions and the anatomical structures detected in the panoramic radiographs.

In conclusion, using only panoramic radiographs is not enough for the detection of the anatomic relationships and borders of the lesions. We suggest that dentists need 3D images to provide the correct information for presurgical assessments.

Key Words: Panoramic radiography, dental tomography, pathology

\section{ÖZET}

Panoramik radyografiler, çenelerdeki lezyonların ve diğer patolojik durumların tespitinde, teknik olarak kolay ve değerli bir yöntemdir. Ancak, bu filmlerin bazı kısıtlılıklarının olduğu bilinmektedir. Bu kısıtlılıkların en önemlileri; distorsiyonlar, magnifikasyonlar ve lezyonların vital yapılarla olan ilişkilerinin belirlenmesindeki zorluklardır.

$\mathrm{Bu}$ çalışmada, panoramik radyografilerin kısıtlılıklarını gösteren iki olgu sunulmuştur. Birinci olguda, panoramik radyografide radyolusent bir lezyon saptandı. Lezyonun sınırlarının, mandibular kanal ve mental foramen ile ilişkili olduğu görüldü. İkinci olguda, panoramik radyografide iki adet radyolusent alan izlendi. Bu alanların, maksiller sinus ve mental foramen ile ilişkide olduğu görüldü. Panoramik görüntülemenin ardından, her iki olgunun da Konik Işınlı Bilgisayarlı Tomografi (KIBT) görüntüleri alındı. KIBT görüntülerinde, lezyonların, panoramik radyografide görülen anatomik yapılar ile ilişkisinin bulunmadığı saptanmıştır.

Sonuç olarak, lezyonların sınırlarının ve anatomik ilişkilerinin belirlenmesinde, panoramik radyografiler tek başına yeterli değildir. Diş hekimlerinin, cerrahi öncesinde doğru teşhis için, üç boyutlu görüntüleme yöntemlerini kullanmalarının gerekli olduğunu düşünmekteyiz.

Anahtar Sözcükler: Panoramik radyografi, dental tomografi, patoloji 


\section{Introduction}

In the practice of oral surgery, detecting the accurate position and course of anatomical landmarks (mandibular canal, mental foramen, maxillary sinus, etc.) is extremely important in preventing complications (1). Panoramic radiographs allow the examination of patients by supplying helpful and even essential information in this regard. It is useful for evaluating the maxillofacial and/or dentoalveolar complex and pathologies of the jaw (2). In addition, the localization of the anatomical structures, eruption and growth patterns of the teeth, and fractures of the jaws should be preoperatively evaluated by these films (3).

In general, most dentists prefer to use panoramic imaging because of its advantages, such as speed, low patient dose, broad anatomic coverage, and high patient acceptability (4). However, several limitations of these radiographs were noted in the literature (1-6). For instance, the image quality of these films is not as sharp as intraoral radiographs. Therefore, the details of cystic and tumoral pathologies may not be clearly identified. Moreover, the amount of magnification and overlapping of the structures may result in a misdiagnosis $(5,6)$.

In this paper, two cases were reported that were evaluated with both panoramic radiographs and cone beam computed tomography (CBCT); (Planmeca ProMax 3D; Rosella, USA) before surgery. We aimed to emphasize the limitations of panoramic radiographs in an oral surgery practice.

\section{Case 1}

A 52-year-old male patient applied to Oral and Maxillofacial Surgery Department, Faculty of Dentistry, Bezmialem Vakif University for a routine dental examination. He had a history of renal transplantation and immunosuppressive drug intake. His intraoral examination revealed that there were tipping of the teeth and restorations in different regions. On the panoramic radiography, a radiolucent lesion with well-defined borders was detected between his right lower canine and premolar teeth. According to the panoramic radiography, it was associated with the mandibular canal and mental foramen (Figure 1). The patient's CBCT scans clearly demonstrated the position of the mental foramen and mandibular canal, and there was no relationship with the cyst cavity (Figure 2 a-e). After written informed consent was obtained from the patient, the lesion was treated with enucleation and curettage under local anesthesia. Postoperatively, there was no evidence of paresthesia or a recurrent or residual lesion.

\section{Case 2}

A 46-year-old female patient was referred to Oral and Maxillofacial Surgery Department, Faculty of Dentistry, Bezmialem Vakif University with a complaint of several missing teeth. Systemically, she was healthy. On examination, decayed teeth and failed full-mouth fixed restorations were observed. On panoramic radiography, two radiolucent areas were detected

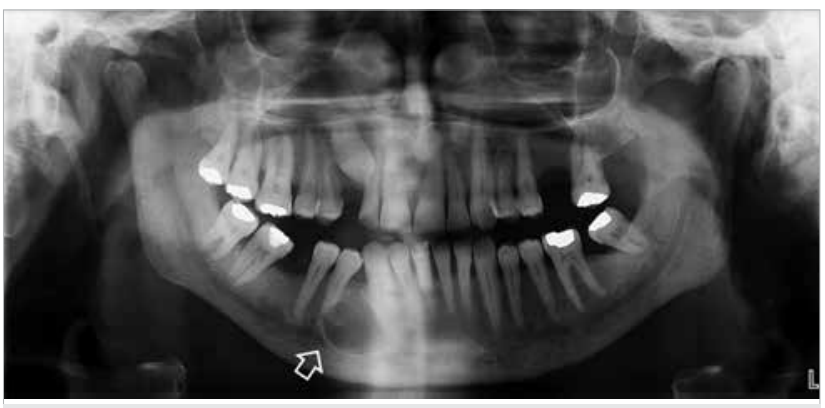

Figure 1. Case \#1. The panoramic radiograph shows the lesion. It seems to be associated with the mandibular canal and mental foremen (white arrow)
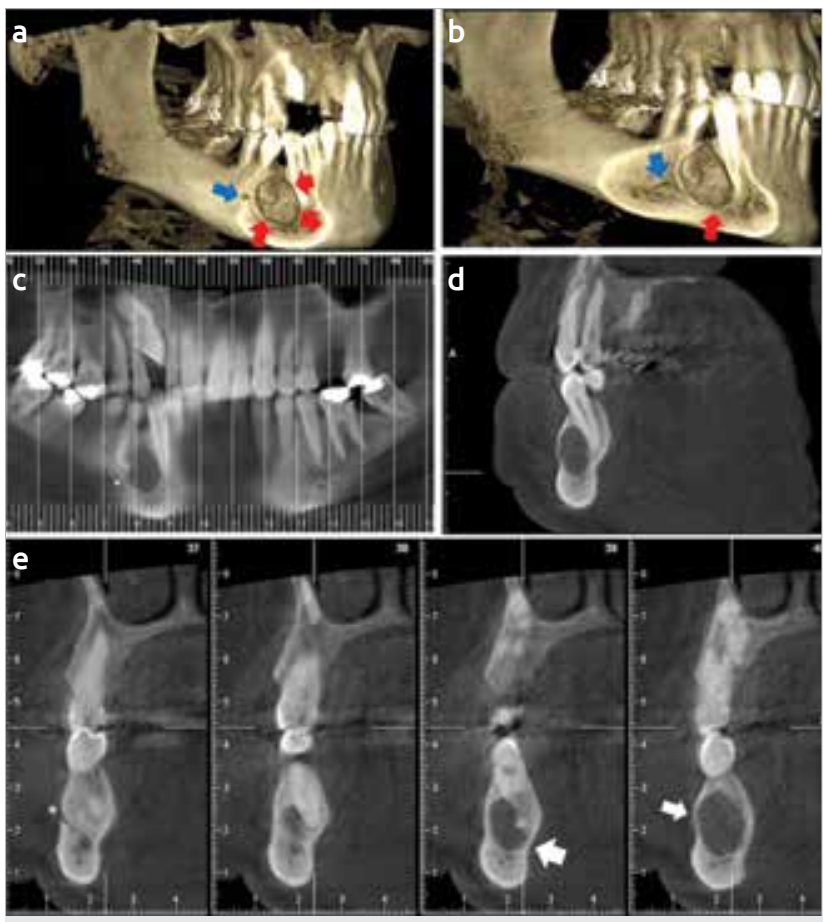

Figure 2. a-e. Case \#1. (A and B) 3-D views show the localization of the lesion and anatomic landmarks: Mental foremen (blue arrow), borders on the cortical bone (red arrows), (C) panoramic reconstruction, (D) and sagittal view of the lesion; (E) lingual and buccal borders of the lesion are clearly seen in the cross-section views (white arrows). section 37 shows the mental foremen (white astral)

on both the maxilla and mandible, and they were noted in relation to the maxillary sinus/nasal cavity and mental foramen (Figure 3). However, the CBCT scans showed that both the maxillary sinus and mental foramen were separated from the cavity of the cystic lesions (Figure 4). The written informed consent was obtained from the patient. The lesions were treated by enucleation with curettage under local anesthesia. This anatomic separation was seen during the surgery (Figure 5). The postoperative period was uneventful.

\section{Discussion}

It is clear that the hard and soft tissues of the oral cavity are related to vital structures, such as the inferior alveolar nerve 


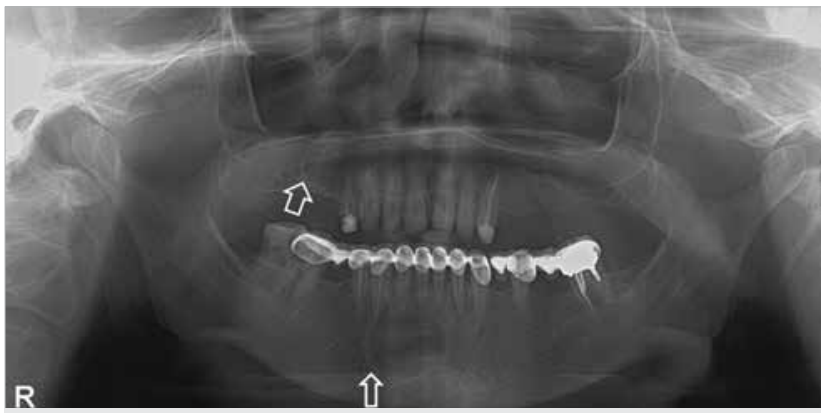

Figure 3. Case \#2. The panoramic radiograph shows the lesions. They seem to be associated with the mandibular canal and mental foremen in the lower jaw and the maxillary sinus and nasal cavity in the upper jaw (white arrows)
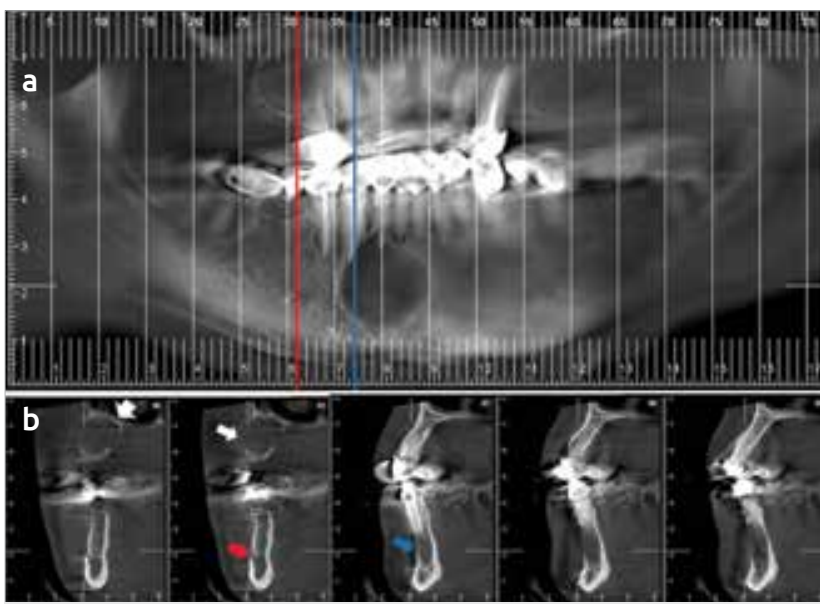

Figure 4. Case \#2. (A) Panoramic reconstruction, (B) crosssection views of the lesion; section 31 shows the localization of mental foremen (red line and arrow), and section 37 shows the distal border of the radicular cyst (blue line and arrow). In the upper jaw, borders of the radicular cyst and intact maxillary sinus floor and nasal cavity appear on the cross-section views (white arrows)
(IAN), the lingual nerve, the mental nerve, the mental foramen, the nasal cavity, and the maxillary sinus. The protection of these structures during surgery is necessary in providing the postoperative morbidity of the patients $(1,5)$. In the cases presented here, the decision was made to perform CBCTs to obtain more precise locations and definitions of the lytic areas. In the CBCT analysis, axial, sagittal, and cross-sectional images and $3 \mathrm{D}$ reconstruction views were used to determine the correct localizations of the anatomical landmarks. In this way, the surgical excisions were performed in a reliable surgical site (7).

Damage to the IAN, lingual nerve, and mental nerve is a serious complication, contributing to the altered sensation of the oral soft tissues, such as the lower lip, chin, buccal gingiva, and tongue. In many cases, panoramic radiographs provide valuable information for the proper diagnosis and surgical management. Blaeser et al. (8) reported that there is an increased risk for nerve injury with positive panoramic radiographic findings, such as the diversion of the inferior alveolar canal, the darkening of the third molar root, and the interruption of the cortical white line. On the other hand, Neves et al. (9) reported an effective adjunct in determining the risk relationship between the tooth roots and mandibular canal, requiring $3 \mathrm{D}$ evaluation of the jaws. In addition, Ezirganli et al. (10) reported that using only panoramic radiographs is not always enough to get the correct diagnosis of jaw pathologies. The presented cases showed the limitations of panoramic radiographs before surgery.

High-resolution cross-sectional images of teeth and the maxillofacial region are provided with $\mathrm{CBCT}$ scans. Intrabony defects, root fractures, and implant areas should be analyzed. It enables the clinician to measure the lengths in the alveolar bone for the presurgical assessment. It can produce different diagnoses and treatment plans in oral surgery (11).
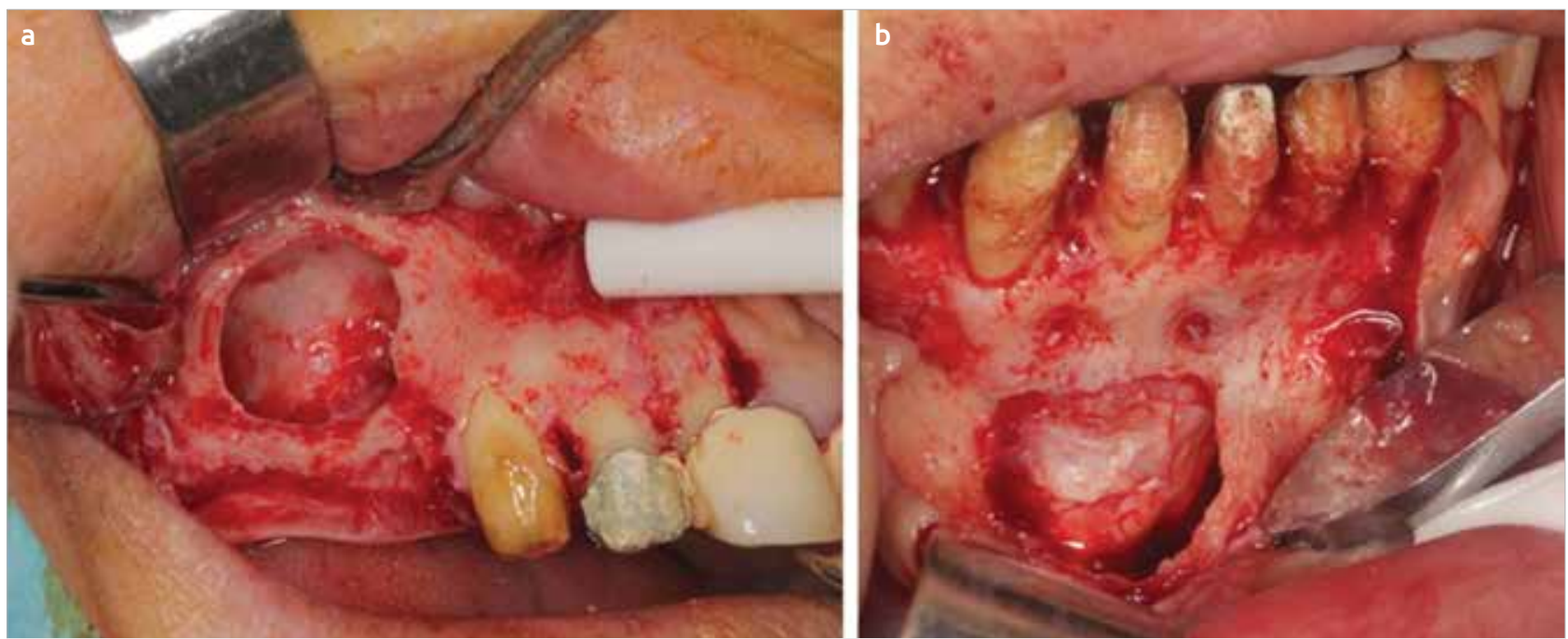

Figure 5. a, b. Case \#2. (A) Photograph of the cyst cavity and surgical site after enucleation of the lesion. (B) Photograph of the cyst membrane and surgical site; it seems that there is no relationship between the cavities and vital anatomical structures 
The principal disadvantages of conventional tomography include higher cost and radiation dose. However, a CBCT provides a lower dose than conventional tomography. Ludlow et al. (12) reported that the dose is related, depending on the field of view (FOV) and selected technical factors. The comparable panoramic examination doses $(6.3 \mathrm{mSv}, 13.3 \mathrm{mSv})$ are 4 to 42 times greater than the CBCT dose.

\section{Conclusion}

In conclusion, the identification of the correct localization of lesions is critically important in maintaining a good preoperative surgical plan and in reducing the risk of nerve injury. Hence, dentists should obtain a dental tomograph if they suspect anatomical relationships with jaw pathologies.

Informed Consent: Written informed consent was obtained from the patients who participated in this case.

Peer-review: Externally peer-reviewed.

Author Contributions: Concept - N.D.; Design - N.D.; Supervision - S.B.; Funding - N.D.; Materials - E.A.; Data Collection and/or Processing - N.D., A.M.; Analysis and/or Interpretation - N.D., A.M.; Literature Review - N.D.E.A.; Writing - N.D.; Critical Review - A.M.

Conflict of Interest: No conflict of interest was declared by the authors.

Financial Disclosure: The authors declared that this study has received no financial support.

Hasta Onamı : Yazılı hasta onamı bu olguya katılan hastadan alınmıştır.

Hakem Değerlendirmesi: Dış bağımsız

Yazar Katkıları: Fikir - N.D.; Tasarım - N.D.; Denetleme S.B.; Kaynaklar - N.D. ; Malzemeler - E.A. ; Veri Toplanması ve/veya İşlemesi - N.D. , A.M. ; Analiz ve/veya Yorum - N.D., A.M. ; Literatür Taraması - N.D. , E.A. ; Yazıyı Yazan - N.D.; Eleştirel İnceleme - A.M.
Çıkar Çatışması: Yazarlar çıkar çatışması bildirmemişlerdir.

Finansal Destek: Yazarlar bu olgu için finansal destek almadıklarını beyan etmişlerdir.

\section{References}

1. Prabhusankar K, Yuvaraj A, Prakash CA, Parthiban J, Praveen B. CBCT cyst lesions diagnosis imaging mandible maxilla. J Clin Diagn Res. 2014; 8: 3-5.

2. Jin-Woo. Assessment of panoramic radiography as a national oral examination tool: review of the literature. Imaging Sci Dent. 2011; 41: 1-6. [CrossRef]

3. Atieh MA. Diagnostic accuracy of panoramic radiography in determining relationship between inferior alveolar nerve and mandibular third molar. J Oral Maxillofac Surg. 2010; 68: 74-82. [CrossRef]

4. Lee GS, Kim JS, Seo YS, Kim JD. Effective dose from direct and indirect digital panoramic units. Imaging Sci Dent. 2013; 43: $77-$ 84. [CrossRef]

5. Kim MS, Yoon SJ, Park HW, Kang JH, Yang SY, Moon YH, et al. A false presence of bifid mandibular canals in panoramic radiographs. Dentomaxillofac Radiol 2011; 40: 434-8. [CrossRef]

6. Dare A, Yamaguchi A, Yoshiki S, Okano T. Limitation of panoramic radiography in diagnosing adenomatoid odontogenic tumors. Oral Surgery, Oral Medicine, and Oral Pathology 1994, 77: 662-8. [CrossRef]

7. Ghaeminia H, Meijer GJ, Soehardi A, Borstlap WA, Mulder J, Bergé SJ. Position of the impacted third molar in relation to the mandibular canal. Diagnostic accuracy of cone beam computed tomography compared with panoramic radiography. Int J Oral Maxillofac Surg. 2009; 38: 964-71. [CrossRef]

8. Blaeser BF, August MA, Donoff RB, Kaban LB, Dodson TB. Panoramic radiographic risk factors for inferior alveolar nerve injury after third molar extraction. J Oral Maxillofac Surg. 2003; 61: 417-21. [CrossRef]

9. Neves FS, Souza TC, Almeida SM, Haiter-Neto F, Freitas DQ, Bóscolo FN. Correlation of panoramic radiography and cone beam CT findings in the assessment of the relationship between impacted mandibular third molars and the mandibular canal Dentomaxillofac Radiol. 2012; 41: 553-7. [CrossRef]

10. Ezirganli Ş, Kazancioğlu HO, Mihmanli, A, Demirtaş N. Çenelerdeki patolojilerin tanısı için panoramik radyografilerin kullanılması her zaman yeterli midir? ADO Klinik Bilimler Dergisi 2012; 6: 1105-8.

11. Haney E, Gansky SA, Lee JS, Johnson E, Maki K, Miller AJ, et al. Comparative analysis of traditional radiographs and cone-beam computed tomography volumetric images in the diagnosis and treatment planning of maxillary impacted canines Am J Orthod Dentofacial Orthop 2010; 137: 590-7. [CrossRef]

12. Ludlow JB, Davies-Ludlow LE, Brooks SL, Howerton WB. Dosimetry of 3 CBCT devices for oral and maxillofacial radiology: CB Mercuray, NewTom 3G and i-CAT. Dentomaxillofac Radiol. 2006; 35: 219-26. [CrossRef] 